GSA DATA REPOSITORY 2019058

\title{
Ongoing Oroclinal bending in the Cascadia forearc and its relation to concave-outboard plate margin geometry
}

\author{
Theron Finley $^{1,2}$, Kristin Morell ${ }^{1,3}$, Lucinda Leonard ${ }^{1}$, Christine Regalla ${ }^{4}$, Stephen T. \\ Johnston $^{2}$, and Wenbo Zhang1,2 \\ ${ }^{1}$ School of Earth and Ocean Sciences, University of Victoria, 3800 Finnerty Rd., Victoria, BC, \\ Canada, V8P 5C2 \\ ${ }^{2}$ Dept. of Earth and Atmospheric Sciences, University of Alberta, 1-26 Earth Sciences Bldg., \\ Edmonton, AB, Canada, T6G $2 E 3$ \\ ${ }^{3}$ Dept. of Earth Sciences, University of California, Santa Barbara, 1006 Webb Hall, Santa \\ Barbara, CA, 93106 \\ ${ }^{4}$ Dept. of Earth and Environment, Boston University, 685 Commonwealth Ave., Boston, MA, \\ U.S.A., 02215
}

Supplementary Data:

- Figure DR1. Structural data from the Olympic Peninsula.

- Table DR1. Comparison between paleomagnetic and GNSS-derived rotation rates in the Cascadia forearc

- Supplemental Methods: GNSS Rotation Analysis 

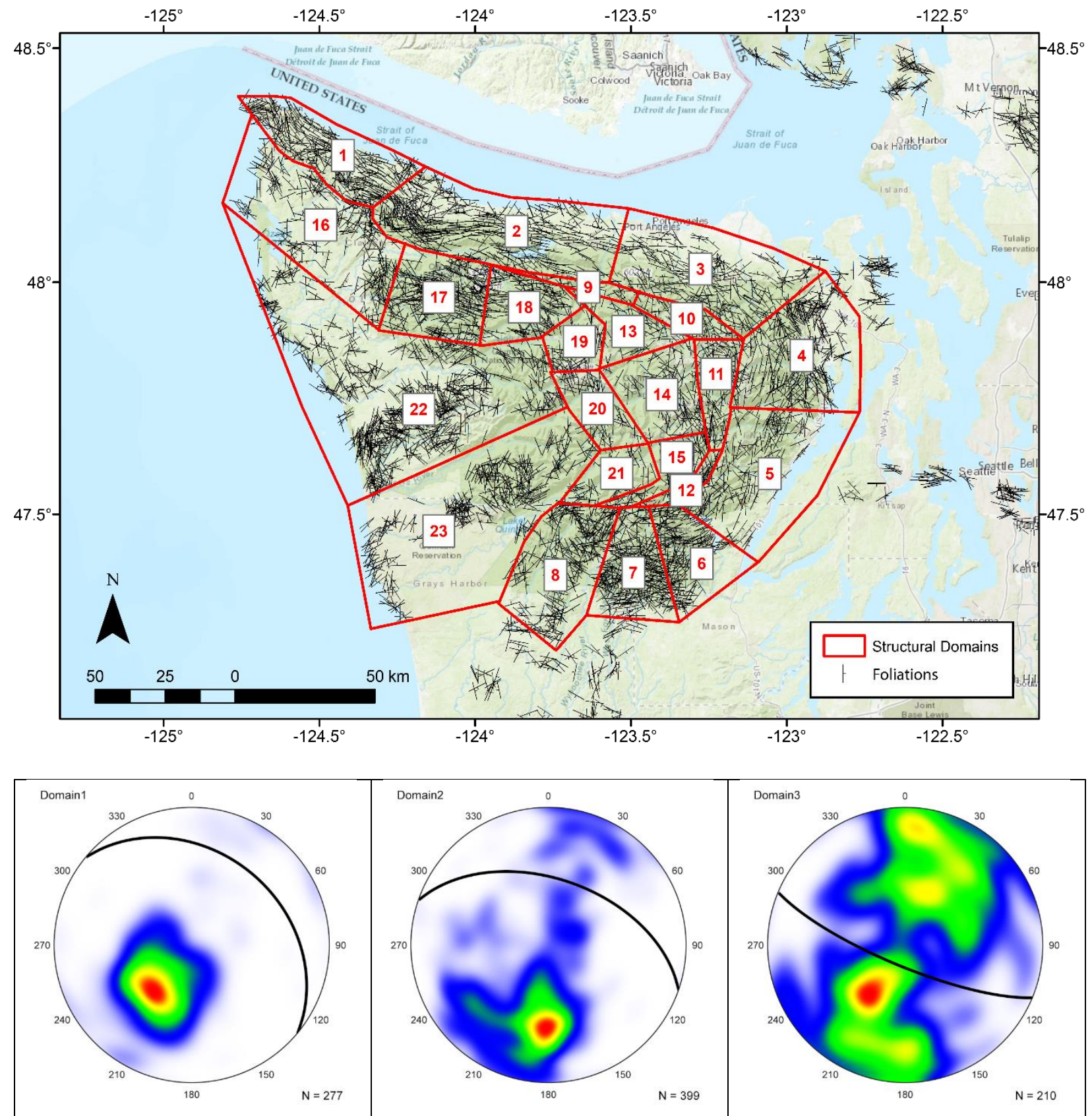

Domain 1: 309/33

Domain 2: 289/50

Domain 3: 113/77 


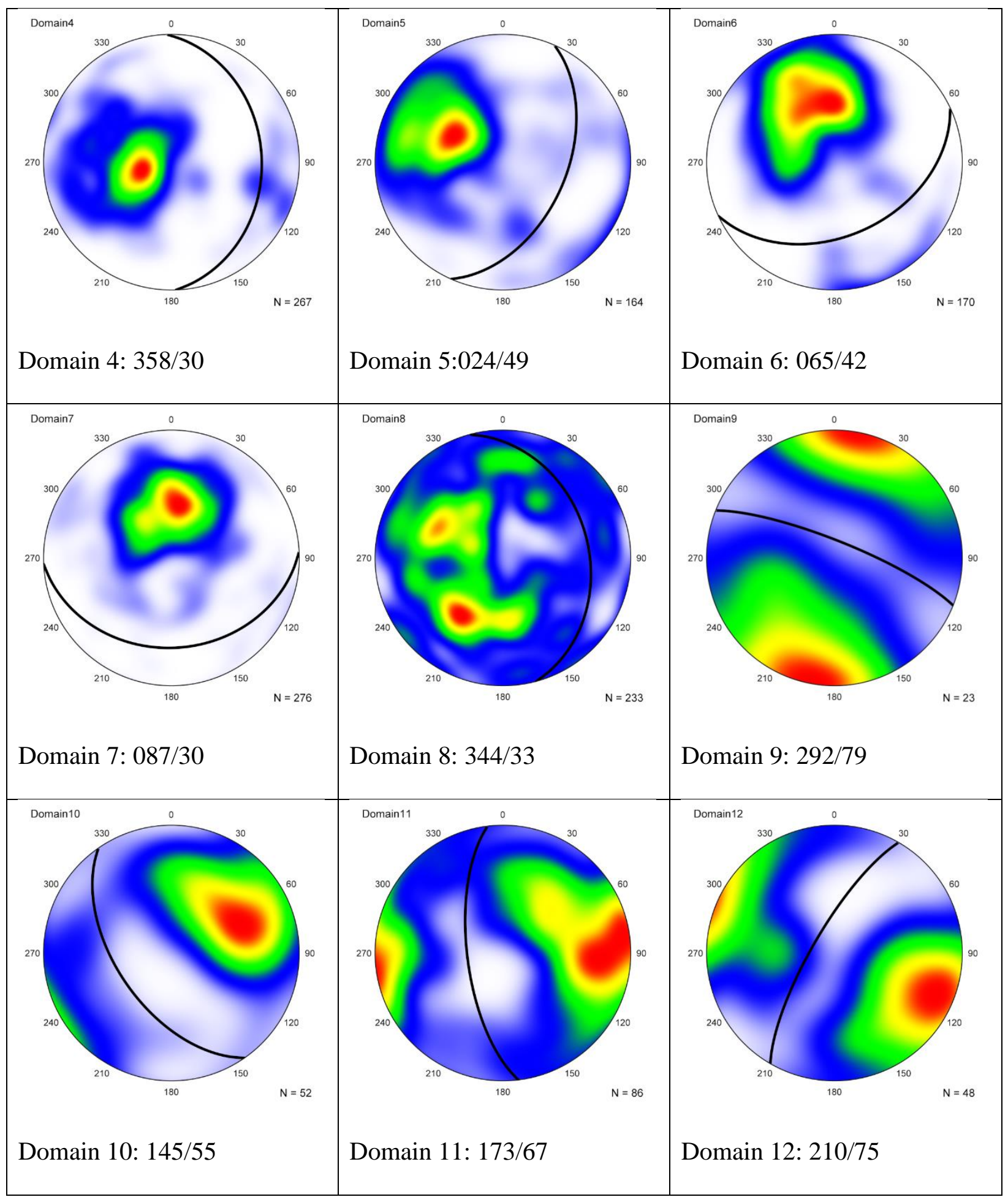




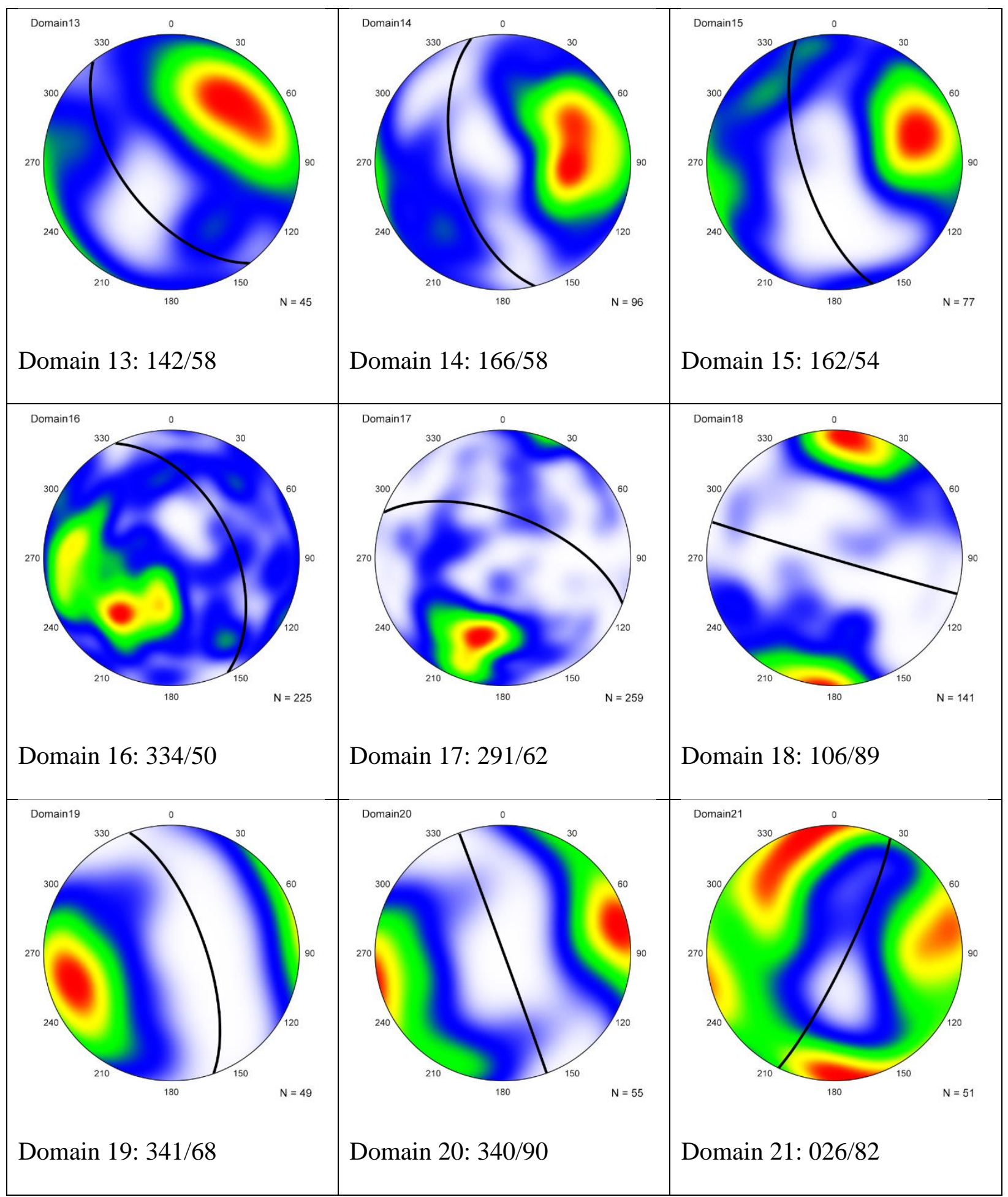




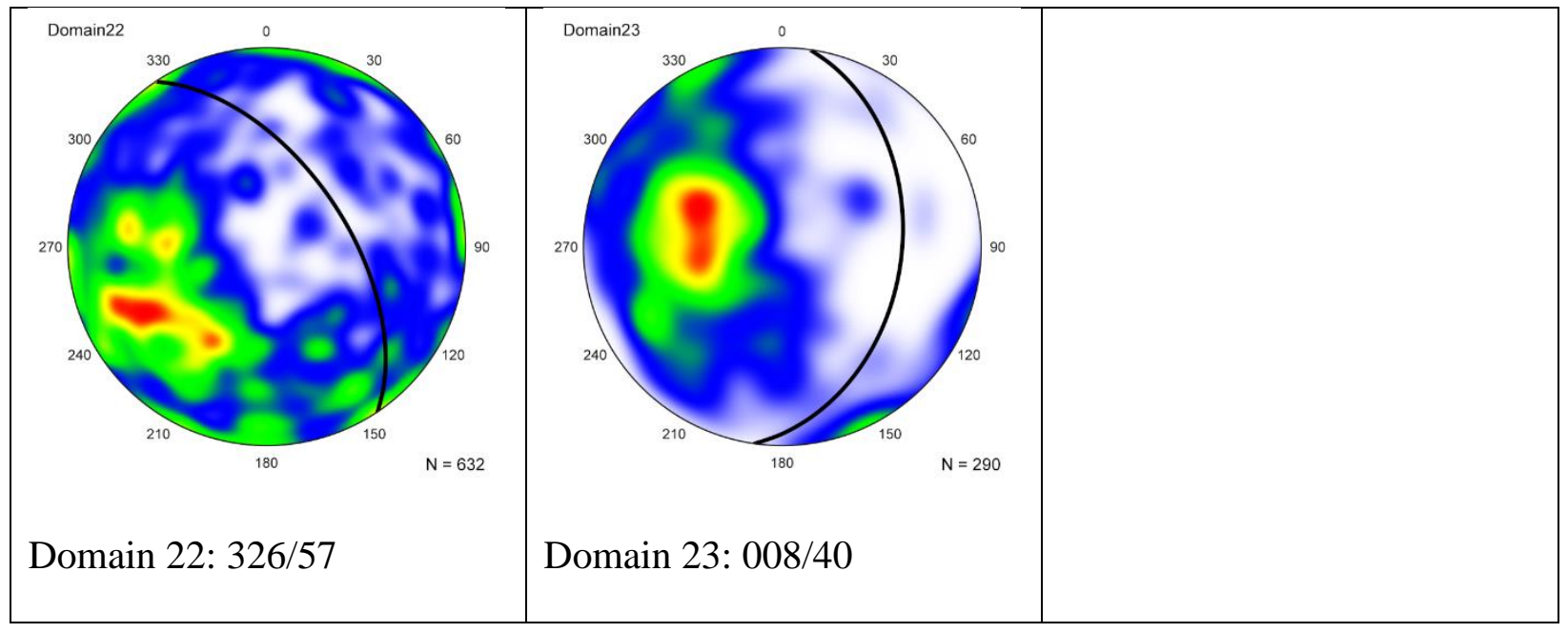

Figure DR1. A: Map of foliation measurements $(n=4125)$ on the Olympic Peninsula (Washington Geological Survey, 2017), divided into 23 structural domains. The outer and inner edges of most domains correspond to major faults, while the along-strike boundaries correspond to obvious changes in strike evident by visual inspection of the data. B: Equal-angle lowerhemisphere stereoplots of foliation data for each structural domain in part A $(n=23)$. Black great circles show the best-fit plane for each domain, while contours show the distribution of poles to all foliation planes in each domain, illustrating the coherence of each dataset; red indicates high concentration of poles, white indicates low concentration. 
Table DR1. Comparison between paleomagnetic and GNSS-derived rotation rates in the Cascadia forearc. Paleomagnetic rotation rates are calculated based on the assumption that oroclinal bending began at $18 \mathrm{Ma}$ at the onset of uplift of the Olympic Mountains. Co-located GNSS rotation rates are taken from grid cells (Fig. 3) overlapping paleomagnetic sample locations. Average rotation rates based on the entire GNSS-rotation dataset are calculated for north and south limbs of the orocline, and for the entire forearc.

\begin{tabular}{|c|c|c|c|c|c|c|c|c|c|}
\hline & \multicolumn{6}{|c|}{ Paleomagnetic Data } & \multicolumn{3}{|c|}{ GNSS Data } \\
\hline & $\begin{array}{l}\text { Sample Site } \\
\left({ }^{\circ} \mathrm{N},{ }^{\circ} \mathrm{E}\right)\end{array}$ & Reference & $\begin{array}{c}\text { Paleomag. } \\
\text { Declination } \\
\left({ }^{\circ}\right)\end{array}$ & $\begin{array}{c}\text { Paleomag. } \\
\text { Rotation Rate } \\
(\% / \mathrm{Myr})\end{array}$ & $\begin{array}{c}\text { Average Limb } \\
\text { Rotation Rate } \\
(\% / \mathrm{Myr})\end{array}$ & $\begin{array}{c}\text { Overall Absolute } \\
\text { Average } \\
\text { Rotation Rate } \\
(\% / \mathrm{Myr})\end{array}$ & $\begin{array}{c}\text { Co-located } \\
\text { GNSS Rotation } \\
\left.\text { Rate ( }{ }^{\circ} / \mathrm{Myr}\right)\end{array}$ & $\begin{array}{c}\text { Average Limb } \\
\text { Rotation Rates } \\
(\% / \mathrm{Myr})\end{array}$ & $\begin{array}{c}\text { Overall Absolute } \\
\text { Average } \\
\text { Rotation Rate } \\
(\% / \mathrm{Myr})\end{array}$ \\
\hline \multirow{3}{*}{$\begin{array}{l}\text { North } \\
\text { Limb }\end{array}$} & $\begin{array}{l}\text { Sooke Formation } \\
(48.4,-123.9)\end{array}$ & Prothero et al. (2008) & $-35 \pm 12$ & $-1.9 \pm 0.7$ & & \multirow{6}{*}{$1.25 \pm 1.0$} & $-0.6 \pm 0.2$ & & \multirow{6}{*}{$0.96 \pm 0.85$} \\
\hline & $\begin{array}{l}\text { East Sooke Gabbro } \\
(48.3,-123.7)\end{array}$ & Symons (1973) & $-20 \pm 7$ & $-1.1 \pm 0.4$ & $-1.3 \pm 1.5$ & & $-0.4 \pm 0.1$ & $-0.94 \pm 0.32$ & \\
\hline & $\begin{array}{l}\text { Port Townsend Basalts } \\
(48.0,-122.7)\end{array}$ & Beck and Engebretson (1982) & $-14 \pm 62$ & $-0.8 \pm 3.4$ & & & $0.2 \pm 0.1$ & & \\
\hline \multirow{3}{*}{$\begin{array}{l}\text { South } \\
\text { Limb }\end{array}$} & $\begin{array}{l}\text { Bremerton Basalts } \\
(47.5,-122.7)\end{array}$ & Beck and Engebretson (1982) & $12 \pm 25$ & $0.7 \pm 1.4$ & \multirow{3}{*}{$1.2 \pm 0.5$} & & $0.7 \pm 0.1$ & \multirow{3}{*}{$0.98 \pm 0.14$} & \\
\hline & $\begin{array}{l}\text { Black Hills Volcanics } \\
(46.9,-123.2)\end{array}$ & Globerman et al. (1982) & $29 \pm 15$ & $1.6 \pm 0.8$ & & & $2.2 \pm 0.2$ & & \\
\hline & $\begin{array}{l}\text { Willapa Hills Volcanics } \\
(46.3,-123.2)\end{array}$ & Wells and Coe (1985) & $24 \pm 10$ & $1.3 \pm 0.6$ & & & $1.1 \pm 0.1$ & & \\
\hline
\end{tabular}




\section{Supplemental Methods: GNSS Rotation Analysis}

We analyzed 25-years' worth of GNSS velocity data from 923 sites from the UNAVCO Plate Boundary Observatory database (https://www.unavco.org/data/gps-gnss/gps-gnss.html) and from McCaffrey et al. (2013) (Figure 2). Continuous GNSS time series ( $n=282$ ) range from years to decades (mean 10.3 years), while campaign site time series $(n=641)$ have an average length of 6.5 years. Uncertainty is typically higher for campaign sites than for continuous sites, and those with exceptionally high uncertainty ( $>5 \mathrm{~mm} / \mathrm{yr}$ ) were removed from the dataset. We used an adaptive Gaussian smoothing function to interpolate crustal velocity at regular grid points spaced by 0.2 degrees of latitude and longitude after Mazzotti et al. (2011). Velocity was calculated at each grid point, as an average of all velocity vectors in the study area, weighted according to standard error and distance to the grid point. An azimuthal weighting factor was also applied to account for the variation in number of GNSS stations over a given azimuthal window $\left(22.5^{\circ}\right)$; lower weight was assigned to stations within a high density sector. The half-width (smoothing distance) of the Gaussian function was defined either by a minimum distance or a distance to the N'th nearest neighbor, whichever was lower, thereby allowing for variable smoothing depending on the density of sites surrounding each grid point. After testing several combinations of smoothing parameters, we selected a minimum distance and N'th nearest neighbor of $50 \mathrm{~km}$ and $\mathrm{N}=5$ respectively, which produced minimal noise while retaining local data structure. To obtain annual rotation rates from velocity, the algorithm calculates the curl of the gridded velocity field with respect to position, the result of which is shown in Fig. 3. Regional patterns in rotational direction (i.e. clockwise versus counterclockwise) were relatively insensitive to changes in smoothing parameters, with key transition zones staying in the same place regardless of the 
Gaussian half-width. Absolute magnitudes of rotation were dampened by broader smoothing functions. Standard error for the resulting rotation field was determined using a Monte Carlo simulation, wherein one thousand random velocities were generated within the uncertainty range of the raw data, and one thousand bootstrap velocities were sampled from the raw data.

\section{References}

Beck, M.E., and Engebretson, D.C., 1982, Paleomagnetism of small basalt exposures in the West Puget Sound Area, Washington, and Speculations on the accretionary origin of the Olympic Mountains: Journal of Geophysical Research, v. 87, p. 3755-3760.

Globerman, B., Beck, M., and Duncan, R., 1982, Paleomagnetism and tectonic significance of Eocene basalts from the Black Hills, Washington Coast Range: Geological Society of America Bulletin, v. 93, p. 1151-1159.

Mazzotti, S., Leonard, L.J., Cassidy, J.F., Rogers, G.C., and Halchuk, S., 2011, Seismic hazard in western Canada from GPS strain rates vs. earthquake catalog: Journal of Geophysical Research, v. 116, B08406, doi: 10.1029/2011JB008213.

McCaffrey, R., King, R.W., Payne, S.J., and Lancaster, M., 2013, Active tectonics of northwestern U.S. inferred from GPS-derived surface velocities: Journal of Geophysical Research: Solid Earth, v. 118, p. 709-723, doi: 10.1029/2012JB009473.

Prothero, D.R., Draus, E., Cockburn, T.C., and Nesbitt, E.A., 2008, Paleomagnetism and counterclockwise tectonic rotation of the Upper Oligocene Sooke Formation, southern Vancouver Island, British Columbia: Canadian Journal of Earth Sciences, v. 45, p. 499-507, doi: 10.1139/E08012.

Symons, D.T.A., 1973, Paleomagnetic Zones in the Oligocene East Sooke Gabro, Vancouver Island, British Columbia: Journal of Geophysical Research, v. 78, p. 5100-5109. 
Washington Geological Survey, 2017, Surface geology, 1:24,000_-GIS data, September 2017:

Washington Geological Survey Digital Data Series DS-10, version 3.0, previously released November 2016.

Wells, R.E., and Coe, R.S., 1985, Paleomagnetism and geology of Eocene volcanic rocks of southwest Washington, implications for mechanisms of tectonic Rotation: Journal of Geophysical Research: Solid Earth, v. 90, p. 1925-1947, doi: 10.1029/JB090iB02p01925. 